\title{
A calendar effect: weekend overreaction (and subsequent reversal) in spot $\mathrm{FX}$ rates
}

\begin{abstract}
This paper investigates a calendar effect, namely the weekend overreaction, in spot foreign exchange markets of 8 major and 9 emerging currencies. We find that after a large price difference between Friday close and subsequent Monday open, most markets are likely to reverse in multiple horizons during the following week, which is consistent with the overreaction hypothesis. We develop a reversal trading strategy to exploit this effect which we show are robust to transaction costs and interest rates. In the out-of-sample test, the strategy is able to generate abnormal risk-adjusted returns, which suggests that these currency markets might be weak-form inefficient.
\end{abstract}

Keywords: Calendar effect; Overreaction; Weekend effect; Market inefficiency; Exchange rates 


\section{Introduction}

Our paper identifies a calendar effect which we observe in the world's largest market, the foreign exchange market. We call this effect 'weekend overreaction'. Specifically, we observe exchange rate behaviours after a large weekend gap (i.e. a large price difference between Friday close and subsequent Monday open) and find significant overreaction in the majority of our sample. After a large weekend gap, most currency markets are likely to reverse in multiple horizons during the following week, which is consistent with the overreaction hypothesis. Out of the 16 currency pairs we examine, only one shows no significant reversal. We develop a reversal trading strategy based on this effect which we show is able to generate abnormal risk-adjusted returns (net of costs) up to more than $10 \%$ per annum. This result suggests that these currency markets might be weak-form inefficient and our study may be of interest to both academics and practitioners. For academics, we document the weekend overreaction and provide evidence against market efficiency while for practitioners, we propose a profitable trading strategy. Our work is motivated by the literature on stock price predictability after large price changes (e.g. Amini et al. 2013) and the vast literature on calendar effects (e.g. Urquhart and McGroarty 2014) as well as the literature on overreaction.

The seminal paper on overreaction by Debondt and Thaler (1985) studied NYSE stocks from 1926 to 1982 and they hypothesise that if markets overshoot systematically, reversals are predictable from past data. Additional research by Debondt and Thaler (1987) shows that the winner-loser effect (i.e. overreaction) is not because of risk change or firm size, which is supported by Alonso and Rubio (1990), who confirm that the overreaction hypothesis is not rejected after considering firm size which only explains a part of profitability. Conversely, Zarowin (1990) replicates Debondt and Thaler (1985) and maintains that overreaction is due to the size effect, yet conceding that although size effect can explain long-term reversals (i.e. several years), short-term overreaction remains unexplained.

In another paper, Fung et al. (2000) report reversals after large overnight price changes in S\&P500 and Hang Seng Index stock futures between 1993 and 1996. The reversal magnitude is commensurate with the size of overnight price gaps and overreaction is a common effect. However, Atkins and Dyl (1990) warn that spreads 
may explain short-term reversals and lead to biased returns without careful consideration. Cox and Peterson (1994) study US stocks from 1963 to 1991 and find that in addition to spreads (i.e. bid-ask bounce), liquidity is important in reversals. Moreover, after a large daily price decline, they observe a momentum effect within 4 -20 days instead of a reversal.

Potential reasons for overreaction include investors' misperception of future cash flows (Debondt and Thaler 1987), firm-specific information or liquidity-motivated trades (Jegadeesh and Titman 1995), analysts' extrapolation of past growth of earnings per share (Bauman et al. 1999), among others. In behavioural finance, attempts to explain reversals include the DHS model (Daniel et al. 2001) and BSV model (Barberis et al. 1998). The DHS model proposes that overreaction is caused by overconfident investors who believe that their information is more accurate than it actually is and the part of their signals reflecting true future price changes is more substantial than it objectively is. Meanwhile, the BSV model postulates that investors believe that earnings switch between mean-reversion and continuation regimes, and overreaction will occur if they believe that the current state is continuation. Although researchers disagree about causes of contrarian profitability, it is statistically and economically significant and not entirely attributable to risk or market frictions (Antoniou et al. 2005).

Regarding the overreaction literature in FX markets, using daily data, Larson and Madura (2001) confirm overreaction in five emerging currencies from 1988 to 1995 while Parikakis and Syriopoulos (2008) examine EUR pairs from 1999 to 2007 and conclude that USD tends to overreact and that contrarian strategies are profitable in FX. Additionally, Goodhart (1988) shows that the GBP/USD pair in the 1980s overshoots using hourly data while Rentzler et al. (2006) report intraday reversals in five currency futures on Chicago Mercantile Exchange from 1988 to 2003 after large one-day returns and opening gaps. In another paper, Ederington and Lee (1995) use tick data from 1988 to 1992 and discover that Deutschemark futures overreact to scheduled macroeconomic news releases in the first 40 seconds after the announcement and reverse in the next few minutes. 
This paper contributes to the literature in two ways. Firstly, this is the first paper to identify the effect of weekend overreaction in spot FX rates. We are motivated by French and Roll (1986) and Ito et al. (1998), who find that asset prices behave differently during exchange trading hours compared to non-trading hours. Specifically, French and Roll (1986) examine US stocks from 1963 to 1982 and find that returns are much more volatile during the trading week than during the weekends. Meanwhile, Ito et al. (1998) analyse the Tokyo FX market from September 1994 to March 1995 and find that the variance of lunch-returns doubles since trading during the lunch break is allowed in December 1994. In our case, because the global FX markets are active around the clock during the weekdays, the natural choice of nontrading periods is the weekends. Our second contribution is that based on this weekend overreaction, we provide evidence against weak-form efficiency using a long dataset of various developed and emerging currencies.

The effect that we find is related to that of Menkhoff et al. (2012) ${ }^{1}$ because we both observe future returns conditional on past returns. However, our effect is different in two ways. The first difference is the timescale of observation. While Menkhoff et al. (2012) observe monthly returns of the subsequent 12 months conditional on the previous 12 months, we observe returns of the subsequent week conditional on the previous weekends. The second difference is the observed directional behaviours of future returns. While Menkhoff et al. (2012) find a momentum effect; we find a reversal effect.

This paper proceeds as follows. Sections 2 and 3 present the data and methodology of tests for overreaction and our reversal trading strategy. Section 4 reports test results and strategy performance. Section 5 discusses the findings and concludes.

\footnotetext{
${ }^{1}$ We thank an anonymous reviewer for mentioning this point.
} 


\section{Data}

We investigate 16 currency pairs including seven major pairs and nine emerging pairs $^{2}$. We have daily spot exchange rates from 1 January 2002 to 31 May 2014 from Bloomberg. Table 1 and 2 provide the descriptive statistics of daily and weekly returns where NZD/USD and TRY/USD have the highest and lowest mean return respectively. Regarding standard deviation, ZAR/USD is the highest and THB/USD is the lowest. Most pairs are negatively skew, all are leptokurtic and all are non-normal, which is confirmed by the Jarque-Bera statistic. Interest rates are also used to calculate the interest on overnight positions. Following Kho (1996) and Qi and Wu (2006), we employ the LIBOR rate (from Bloomberg) and for emerging currencies whose LIBORs are unavailable, we employ domestic bank rates from Datastream.

Table 1. The descriptive statistics of daily FX returns where a superscript denotes significance at $1 \%$. Panel A and B include major and emerging currencies respectively.

\begin{tabular}{|c|c|c|c|c|c|}
\hline & Mean $(\%)$ & $\begin{array}{c}\text { Standard } \\
\text { deviation }(\%)\end{array}$ & Skewness & Kurtosis & $\begin{array}{c}\text { Jarque-Bera } \\
\text { normality }\end{array}$ \\
\hline \multicolumn{6}{|c|}{ Panel A: Major Currencies } \\
\hline EUR/USD & 0.013 & 0.622 & 0.016 & 4.526 & $314^{\mathrm{a}}$ \\
\hline JPY/USD & 0.008 & 0.646 & -0.066 & 7.064 & $2231^{\mathrm{a}}$ \\
\hline GBP/USD & 0.004 & 0.573 & -0.327 & 5.564 & $945^{\mathrm{a}}$ \\
\hline AUD/USD & 0.019 & 0.858 & -0.419 & 13.418 & $14737^{\mathrm{a}}$ \\
\hline CHF/USD & 0.019 & 0.696 & -0.539 & 14.558 & $18181^{\mathrm{a}}$ \\
\hline CAD/USD & 0.012 & 0.611 & -0.162 & 5.774 & $1052^{\mathrm{a}}$ \\
\hline NZD/USD & 0.022 & 0.857 & -0.397 & 6.014 & $1311^{\mathrm{a}}$ \\
\hline \multicolumn{6}{|c|}{ Panel B: Emerging Currencies } \\
\hline BRL/USD & -0.001 & 1.090 & -0.356 & 12.588 & $12470^{\mathrm{a}}$ \\
\hline $\mathrm{CZK} / \mathrm{USD}$ & 0.018 & 0.827 & -0.138 & 5.904 & $1148^{\mathrm{a}}$ \\
\hline INR/USD & -0.004 & 0.480 & -0.019 & 9.397 & $5521^{\mathrm{a}}$ \\
\hline IDR/USD & -0.004 & 0.622 & -0.639 & 22.364 & $50776^{\mathrm{a}}$ \\
\hline MXN/USD & -0.007 & 0.740 & 0.964 & 40.268 & $187770^{\mathrm{a}}$ \\
\hline PLN/USD & 0.008 & 0.949 & -0.220 & 6.758 & $1931^{\mathrm{a}}$ \\
\hline ZAR/USD & 0.004 & 1.166 & -1.024 & 15.311 & $21009^{a}$ \\
\hline THB/USD & 0.009 & 0.449 & -1.709 & 39.020 & $176622^{a}$ \\
\hline TRY/USD & -0.011 & 0.917 & -0.604 & 9.217 & $5409^{\mathrm{a}}$ \\
\hline
\end{tabular}

Table 2. The descriptive statistics of weekly FX returns where ${ }^{a}$ superscript denotes significance at $1 \%$. Panel A and B include major and emerging currencies respectively.

\begin{tabular}{|c|c|c|c|c|c|}
\hline & Mean $(\%)$ & $\begin{array}{c}\text { Standard } \\
\text { deviation }(\%)\end{array}$ & Skewness & Kurtosis & $\begin{array}{c}\text { Jarque-Bera } \\
\text { normality }\end{array}$ \\
\hline \multicolumn{6}{|c|}{ Panel A: Major Currencies } \\
\hline EUR/USD & 0.065 & 1.381 & -0.401 & 4.302 & $63^{\mathrm{a}}$ \\
\hline JPY/USD & 0.039 & 1.423 & 0.278 & 4.297 & $54^{\mathrm{a}}$ \\
\hline GBP/USD & 0.023 & 1.325 & -0.710 & 7.034 & $493^{\mathrm{a}}$ \\
\hline AUD/USD & 0.090 & 1.898 & -1.805 & 18.767 & $7053^{a}$ \\
\hline CHF/USD & 0.095 & 1.508 & -0.519 & 8.088 & $727^{\mathrm{a}}$ \\
\hline CAD/USD & 0.060 & 1.319 & -0.791 & 7.794 & $687^{\mathrm{a}}$ \\
\hline NZD/USD & 0.105 & 1.936 & -0.844 & 5.995 & $319^{a}$ \\
\hline \multicolumn{6}{|c|}{ Panel B: Emerging Currencies } \\
\hline BRL/USD & 0.006 & 2.211 & -0.922 & 8.029 & $773^{\mathrm{a}}$ \\
\hline CZK/USD & 0.088 & 1.807 & -0.358 & 4.000 & $41^{\mathrm{a}}$ \\
\hline INR/USD & -0.032 & 0.988 & -0.326 & 6.055 & $263^{a}$ \\
\hline IDR/USD & -0018 & 1.197 & -0758 & 9965 & $1370^{\mathrm{a}}$ \\
\hline
\end{tabular}




\section{Methodology}

\subsection{Overreaction hypothesis}

We test the weekend overreaction in spot FX markets using the method of a closely related study by Rentzler et al. (2006), who investigate intraday reversals in currency futures after large opening gaps (i.e. the non-trading period from the close of the previous trading day to the open of the current trading day). Because our focus is weekend overreaction, the initial extreme movements are represented by large upward and downward price changes between Friday close and subsequent Monday open (hereafter, weekend gaps). These gaps may be caused by new price-relevant information over the weekends. If there is new information over the weekends which has clear and strong implications on the exchange rates, a large gap should occur when markets open on Monday to reflect this information. McFarland et al. (1982) state that during the weekends, information flows more actively in FX than in other markets and that price changes on Monday reflect weekend events. Moreover, Rogalski (1984) finds that the well-known weekend effect in the literature indeed occurs in the non-trading period from Friday close to Monday open and may be due to information released during the weekends. ${ }^{3}$

Following Rentzler et al. (2006), we define large weekend gaps as the top and bottom $5 \%$ quantile of weekend returns. More specifically, we sort the weekend returns from highest to lowest and select the highest 5\% quantile as large upward gaps and the lowest 5\% quantile as large downward gaps. We use a relative threshold (i.e. quantile)

\footnotetext{
${ }^{3}$ We thank an anonymous reviewer for suggesting this discussion.
} 
to define extreme returns instead of an absolute value because an absolute value may be considered extreme for one time series but may not be for another, so it is better to let the time series itself decide how extreme is extreme. To be more comprehensive, we also consider other thresholds in addition to 5\%. There is a trade-off between the extremeness of the threshold and the number of observations (i.e. the number of 'extreme return' observations decreases when the threshold becomes more extreme and vice versa). Because we need both a reasonable number of observations and sufficiently extreme returns to study overreaction, we consider $5 \%, 10 \%$ and $15 \%$ thresholds. Regarding the observation horizons after the gaps, we consider one-day, three-day and one-week horizons. The returns are calculated as follows.

$$
\begin{gathered}
\text { weekend gap return }=\ln \left(\frac{\text { current Monday open } F X \text { rate }}{\text { previous Friday close FX rate }}\right) \\
\text { one-day return }=\ln \left(\frac{\text { current Monday close } F X \text { rate }}{\text { current Monday open } F X \text { rate }}\right) \\
\text { three-day return }=\ln \left(\frac{\text { current } W \text { ednesday close FX rate }}{\text { current Monday open } F X \text { rate }}\right) \\
\text { one- week return }=\ln \left(\frac{\text { current Friday close } F X \text { rate }}{\text { current Monday open } F X \text { rate }}\right)
\end{gathered}
$$

The global FX market is open 24 hours a day; the trading week starts in Australia at 10pm GMT on Sunday and ends in the US at 10pm GMT on Friday. In equation (1) (4), the Monday open refers to the Monday open of Australia (i.e. at 10pm GMT on the previous day), the close rates refer to the close of the US (i.e. at 10pm GMT on the same day). It is worth noting that a trading day in the global FX market consists of several international sessions, among which trading activities can be different ${ }^{4}$. To be more informative, we also examine two intraday periods which both start at the Australian open and end at the European open (i.e. at 8am GMT on the same day) and US open (i.e. at $1 \mathrm{pm}$ GMT on the same day) respectively. The mean returns of weekend gaps and subsequent horizons are calculated separately for two cases, namely upward and downward gaps. If overreaction exists, the mean returns of the horizons after a large upward (downward) gap should be negative (positive).

\footnotetext{
${ }^{4}$ We thank an anonymous reviewer for pointing this out.
} 


\subsection{Trading strategy}

We develop a reversal trading strategy and summarise it in Table 3 . We test this strategy out-of-sample to examine its performance in real time. The out-of-sample test starts in January 2007, which means in the first week of 2007, a trade will be initiated if the weekend gap exceeds the 'large gap' threshold estimated by the top and bottom quantiles of weekend returns during $2002-2006$ period. The window for estimation is from January 2002 to December 2006 which is five years' worth of weekly observations (because there is one weekend return every week). Including the financial crisis in the out-of-sample period helps us test the robustness of the trading strategy. The test moves forward week by week until May 2014, using both recursive and rolling estimation of large gaps.

Table 3. Summary of the reversal trading strategy. This table describes different aspects of our reversal trading strategy.

\begin{tabular}{|c|c|}
\hline Trading style & Contrarian \\
\hline Trading idea & Based on overreaction \\
\hline Trade entry signal & large weekend gaps (i.e. top and bottom quantiles of gap returns) \\
\hline Trade entry time & Monday open \\
\hline Trade direction & Opposite to the direction of the weekend gaps \\
\hline Holding period & $\begin{array}{c}\text { Because this strategy is based on overreaction, we choose the horizon } \\
\text { which shows the most significant results in our prior tests for } \\
\text { overreaction as the holding period. }\end{array}$ \\
\hline Trade exit signal & End of holding period \\
\hline
\end{tabular}

To discuss market efficiency, we follow Jensen (1978), who states that although the Efficient Market Hypothesis has been presented in different ways, its most general interpretation is that if the market is efficient with respect to a given information set, economic profits (defined as risk-adjusted returns after deducting costs) cannot be made by using this information set. Because the relevant information set for weakform efficiency is past data, the market is weak-form efficient if abnormal riskadjusted returns (net of costs) cannot be made by using past prices. To obtain abnormal risk-adjusted returns, we regress returns of the trading strategy against the currency risk factors used by Lustig et al. (2011), namely the average return of 
currency market and the return of carry trade (i.e. buying high-interest currencies and selling low-interest currencies). If the market is weak-form efficient, active trading based on price patterns cannot generate statistically significant positive abnormal returns. Regarding strategy evaluation, let us consider the return of a long and short position in foreign currency from the perspective of US investors.

Figure 1. Long and short positions in foreign currency. This figure illustrates the process of opening and closing long and short positions in a foreign currency. The domestic currency is USD.

A. Long Positions

\begin{tabular}{|c|c|c|c|}
\hline $\begin{array}{c}\text { Exchange domestic } \\
\text { currency for foreign } \\
\text { currency (open } \\
\text { positions) }\end{array}$ & $\begin{array}{c}\text { Lend foreign } \\
\text { currency during } \\
\text { the trading } \\
\text { horizon }\end{array}$
\end{tabular}$\rightarrow$\begin{tabular}{c}
$\begin{array}{c}\text { Exchange foreign } \\
\text { currency for } \\
\text { domestic currency } \\
\text { (close positions) }\end{array}$ \\
\cline { 2 - 3 }
\end{tabular}

B. Short Positions

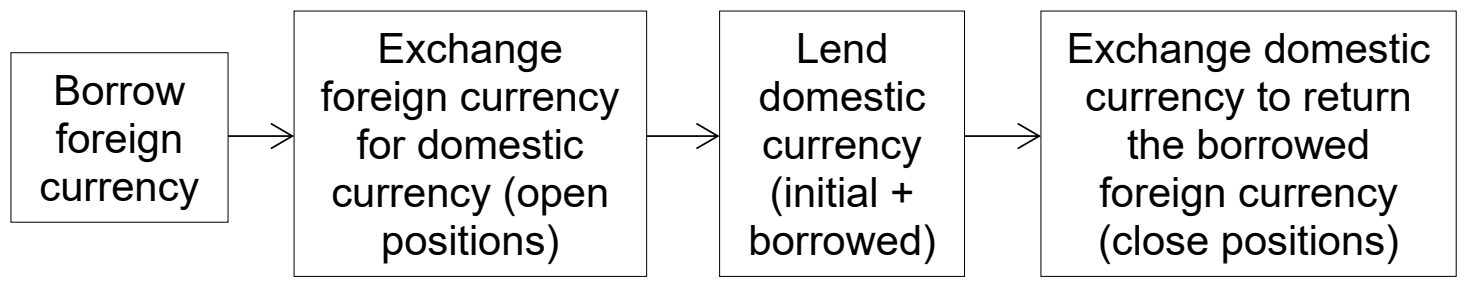

The respective returns of a long and short position are as follows.

$$
\begin{gathered}
R_{\text {long }, t}=\ln \left(s_{t} / s_{t-1}\right)+r_{b, t}-C \\
R_{\text {short }, t}=-\ln \left(s_{t} / s_{t-1}\right)-r_{b, t}+2 r_{q, t}-C
\end{gathered}
$$

Equation (5) and (6) can be transformed into

$$
\begin{gathered}
R_{\text {long }, t}=\left[\ln \left(s_{t} / s_{t-1}\right)+r_{b, t}-r_{q, t}\right]+r_{q, t}-C \\
R_{\text {short }, t}=-\left[\ln \left(s_{t} / s_{t-1}\right)+r_{b, t}-r_{q, t}\right]+r_{q, t}-C
\end{gathered}
$$

Returns of long and short positions can be combined as

$$
R_{t}=\left[\ln \left(s_{t} / s_{t-1}\right)+r_{b, t}-r_{q, t}\right] \cdot S_{t-1}+r_{q, t}-C
$$

$\mathrm{S}$ is a signal function which transforms trade triggers into positions (White 2000) by taking the value of 1 or -1 for long or short positions respectively. $t-1$ and tenote the time of opening and closing positions, $\mathrm{R}$ is the return, $\mathrm{s}$ is the spot FX rate, $r_{b, t}$ and 
$r_{q, t}$ are respective interest rates of the base and quote currency from t- 1 to $t$. In our data, the exchange rates are quoted as the price of the foreign currency in USD (i.e. the domestic currency), in other words, how many US dollars are equal to one unit of foreign currency. Therefore, the foreign currency is the base currency and the domestic currency is the quote currency. $\mathrm{C}$ is the round-trip transaction cost which we set to $0.08 \%$ for major pairs in line with Bessembinder (1994) and 0.3\% for emerging pairs as suggested by Kuang et al. (2014). Because $r_{q, t}$ is the return from lending the quote currency (USD, which investors start with) during the trading horizon, it can be considered the risk-free rate. Therefore, the excess return of each trade is obtained by deducting $r_{q, t}$ from equation (9).

$$
E R_{t}=\left[\ln \left(s_{t} / s_{t-1}\right)+r_{b, t}-r_{q, t}\right] \cdot S_{t-1}-C
$$

ER is excess return. Also, when there is no trading signal, investors earn the risk-free rate $r_{q, t}$ so the excess return is zero. Finally, to discuss market efficiency, we regress the excess return against two risk factors used in Lustig et al. (2011). The first factor is the average currency return (denoted as RX), which is the return of a portfolio including all 16 currencies in our sample. The second factor is the carry trade return (denoted as HML), which is the return difference between a portfolio including the 8 highest-interest currencies and a portfolio including the 8 lowest-interest currencies. The regression is as follows.

$$
E R_{t}=\alpha+\beta_{R X} R X_{t}+\beta_{H M L} H M L_{t}+\varepsilon_{t}
$$

$\varepsilon_{t}$ is the error term. If the currency market is efficient, the abnormal return $\alpha$ should not be positive with statistical significance.

\section{Results}

\subsection{Overreaction hypothesis}

Table $4-6$ below report the results of the overreaction test using the top and bottom $5 \%, 10 \%$ and $15 \%$ quantiles of weekend returns as large gaps. 
Table 4. The mean returns (\%) of large weekend gaps and subsequent horizons in the overreaction test using the top and bottom $5 \%$ quantile as large gaps where ${ }^{\mathrm{a}}{ }^{\mathrm{b}}$ and ${ }^{\mathrm{c}}$ superscripts denote significance (i.e. difference from zero) at 1\%,5\% and $10 \%$ levels respectively. The third row shows the end of the horizons including the European open (EU open) and US open for intraday horizons and the US close for daily horizons. All horizons start after the large weekend gap at the Australian open (AU open) on Monday. Panel A and B include major and emerging currencies respectively.

\begin{tabular}{|c|c|c|c|c|c|c|c|c|c|c|c|c|}
\hline & \multicolumn{6}{|c|}{ Upward gaps } & \multicolumn{6}{|c|}{ Downward gaps } \\
\hline & Large gap & & One-day & & Three-day & One-week & Large gap & & One-day & & Three-day & One-week \\
\hline & AU open & EU open & US open & US close & US close & US close & AU open & EU open & US open & US close & US close & US close \\
\hline \multicolumn{13}{|c|}{ Panel A: Major Currencies } \\
\hline EUR/USD & 0.374 & -0.003 & $-0.281^{a}$ & $-0.238^{b}$ & $-0.727^{a}$ & $-0.451^{\mathrm{c}}$ & -0.409 & 0.006 & -0.035 & 0.135 & 0.209 & 0.236 \\
\hline JPY/USD & 0.537 & -0.043 & 0.110 & $-0.299^{b}$ & -0.163 & 0.135 & -0.444 & $0.148^{b}$ & $0.183^{b}$ & $0.322^{\mathrm{a}}$ & $0.634^{\mathrm{a}}$ & 0.124 \\
\hline GBP/USD & 0.330 & -0.104 & -0.117 & -0.224 & -0.214 & -0.605 & -0.319 & 0.013 & -0.052 & 0.262 & 0.192 & 0.461 \\
\hline AUD/USD & 0.570 & 0.101 & 0.209 & 0.146 & -0.079 & 0.104 & -0.434 & 0.008 & 0.016 & 0.179 & -0.264 & 0.579 \\
\hline CHF/USD & 0.501 & $-0.217^{b}$ & $-0.229^{c}$ & $-0.267^{c}$ & -0.209 & 0.022 & -0.403 & 0.009 & -0.010 & $0.284^{\mathrm{b}}$ & -0.142 & $0.401^{\mathrm{c}}$ \\
\hline NZD/USD & 0.461 & -0.025 & 0.017 & -0.037 & -0.095 & $-1.160^{b}$ & -0.575 & 0.056 & 0.155 & $0.298^{c}$ & 0.209 & $0.930^{\mathrm{c}}$ \\
\hline Panel mean & 0.444 & -0.040 & -0.018 & $-0.131^{\mathrm{c}}$ & -0.184 & -0.326 & -0.407 & $0.047^{\mathrm{c}}$ & 0.055 & $0.239^{\mathrm{a}}$ & 0.168 & $0.431^{\mathrm{a}}$ \\
\hline \multicolumn{13}{|c|}{ Panel B: Emerging Currencies } \\
\hline BRL/USD & 0.855 & -0.033 & $-0.025^{c}$ & -0.073 & $-0.860^{b}$ & $-1.070^{c}$ & -0.984 & 0.065 & 0.143 & 0.155 & 0.583 & -0.156 \\
\hline CZK/USD & 0.646 & -0.153 & -0.152 & $-0.426^{\mathrm{a}}$ & -0.090 & $-0.851^{\mathrm{c}}$ & -0.622 & 0.023 & 0.039 & $0.336^{c}$ & 0.126 & 0.203 \\
\hline INR/USD & 0.767 & $-0.236^{a}$ & $-0.237^{a}$ & $-0.383^{a}$ & 0.045 & -0.252 & -0.641 & -0.039 & -0.004 & $0.244^{\mathrm{c}}$ & 0.190 & -0.191 \\
\hline IDR/USD & 0.912 & -0.114 & -0.068 & $-0.640^{\mathrm{a}}$ & -0.158 & $-0.694^{c}$ & -0.999 & $0.112^{\mathrm{c}}$ & $0.143^{c}$ & $0.454^{\mathrm{b}}$ & 0.074 & $0.880^{\mathrm{a}}$ \\
\hline MXN/USD & 0.424 & -0.009 & 0.050 & -0.164 & -0.008 & $-1.068^{a}$ & -0.604 & $0.152^{b}$ & -0.010 & 0.292 & 0.083 & 0.584 \\
\hline PLN/USD & 0.722 & -0.004 & $-0.370^{c}$ & $-0.572^{a}$ & -0.286 & $-1.154^{c}$ & -0.678 & -0.152 & -0.003 & 0.104 & 0.195 & 0.206 \\
\hline THB/USD & 0.583 & $-0.674^{\mathrm{c}}$ & -0.343 & $-0.393^{a}$ & -0.085 & -0.103 & -0.808 & -0.219 & 0.042 & $0.356^{\mathrm{b}}$ & 0.094 & 0.258 \\
\hline TRY/USD & 0.738 & $-0.268^{a}$ & 0.031 & 0.223 & -0.479 & 0.107 & -0.751 & 0.048 & 0.079 & 0.283 & -0.301 & 0.361 \\
\hline Panel mean & 0.718 & $-0.198^{b}$ & $-0.158^{b}$ & $-0.436^{\mathrm{a}}$ & $-0.294^{b}$ & $-0.774^{\mathrm{a}}$ & -0.769 & 0.012 & $0.047^{\mathrm{c}}$ & $0.305^{\mathrm{a}}$ & 0.114 & $0.332^{b}$ \\
\hline
\end{tabular}


Table 5. The mean returns (\%) of large weekend gaps and subsequent horizons in the overreaction test using the top and bottom $10 \%$ quantile as large gaps where a ${ }^{b}$ and $^{\mathrm{c}}$ superscripts denote significance (i.e. difference from zero) at $1 \%, 5 \%$ and $10 \%$ levels respectively. The third row shows the end of the horizons including the European open (EU open) and US open for intraday horizons and the US close for daily horizons. All horizons start after the large weekend gap at the Australian open (AU open) on Monday. Panel A and B include major and emerging currencies respectively.

\begin{tabular}{|c|c|c|c|c|c|c|c|c|c|c|c|c|}
\hline & \multicolumn{6}{|c|}{ Upward gaps } & \multicolumn{6}{|c|}{ Downward gaps } \\
\hline & Large gap & & One-day & & Three-day & One-week & Large gap & & One-day & & Three-day & One-week \\
\hline & AU open & EU open & US open & US close & US close & US close & AU open & EU open & US open & US close & US close & US close \\
\hline \multicolumn{13}{|c|}{ Panel A: Major Currencies } \\
\hline EUR/USD & 0.299 & -0.001 & $-0.157^{b}$ & $-0.313^{\mathrm{a}}$ & $-0.580^{\mathrm{a}}$ & $-0.436^{b}$ & -0.368 & -0.007 & -0.071 & -0.001 & 0.107 & 0.266 \\
\hline JPY/USD & 0.446 & -0.066 & -0.007 & -0.061 & -0.168 & -0.116 & -0.359 & $0.104^{\mathrm{b}}$ & $0.116^{\mathrm{b}}$ & $0.183^{b}$ & $0.334^{\mathrm{b}}$ & 0.303 \\
\hline GBP/USD & 0.287 & $-0.094^{b}$ & -0.081 & -0.044 & -0.099 & -0.115 & -0.301 & 0.036 & -0.080 & 0.061 & 0.200 & 0.128 \\
\hline AUD/USD & 0.486 & 0.007 & -0.007 & 0.002 & -0.046 & 0.019 & -0.361 & 0.034 & 0.051 & 0.129 & -0.037 & 0.056 \\
\hline $\mathrm{CHF} / \mathrm{USD}$ & 0.417 & $-0.155^{\mathrm{a}}$ & $-0.154^{b}$ & $-0.236^{\mathrm{a}}$ & -0.072 & -0.112 & -0.333 & 0.032 & 0.063 & 0.079 & -0.008 & -0.014 \\
\hline NZD/USD & 0.424 & -0.070 & -0.091 & -0.140 & -0.256 & -0.167 & -0.468 & 0.018 & -0.053 & 0.044 & 0.227 & 0.360 \\
\hline Panel mean & 0.369 & $-0.051^{c}$ & -0.060 & -0.091 & $-0.163^{c}$ & -0.114 & -0.335 & $0.039^{\mathrm{b}}$ & 0.014 & $0.077^{\mathrm{b}}$ & $0.149^{b}$ & $0.164^{b}$ \\
\hline \multicolumn{13}{|c|}{ Panel B: Emerging Currencies } \\
\hline BRL/USD & 0.642 & -0.041 & $-0.018^{c}$ & -0.051 & $-0.565^{a}$ & $-0.745^{a}$ & -0.455 & 0.053 & $0.112^{\mathrm{c}}$ & 0.076 & 0.100 & -0.133 \\
\hline CZK/USD & 0.407 & -0.076 & -0.076 & -0.101 & -0.055 & -0.176 & -0.391 & 0.004 & 0.034 & 0.055 & 0.244 & 0.352 \\
\hline INR/USD & 0.603 & $-0.228^{\mathrm{a}}$ & $-0.267^{\mathrm{a}}$ & $-0.162^{a}$ & -0.249 & -0.126 & -0.272 & -0.020 & -0.007 & $0.123^{b}$ & 0.126 & $0.183^{\mathrm{c}}$ \\
\hline IDR/USD & 0.580 & $-0.122^{b}$ & $-0.135^{b}$ & $-0.210^{\mathrm{a}}$ & $-0.306^{a}$ & $-0.286^{a}$ & -0.653 & $0.051^{\mathrm{c}}$ & $0.087^{b}$ & $0.150^{\mathrm{a}}$ & 0.070 & -0.142 \\
\hline MXN/USD & 0.313 & -0.004 & 0.034 & 0.016 & 0.088 & 0.188 & -0.456 & $0.065^{\mathrm{c}}$ & -0.021 & $-0.125^{c}$ & -0.090 & -0.286 \\
\hline PLN/USD & 0.516 & 0.054 & $-0.231^{b}$ & $-0.243^{c}$ & -0.159 & -0.265 & -0.494 & -0.072 & 0.029 & -0.068 & 0.129 & 0.203 \\
\hline THB/USD & 0.189 & $-0.349^{c}$ & $-0.193^{c}$ & $-0.090^{\mathrm{c}}$ & -0.012 & 0.022 & -0.453 & -0.295 & 0.010 & 0.069 & 0.064 & 0.115 \\
\hline TRY/USD & 0.310 & $-0.161^{a}$ & -0.061 & -0.134 & -0.325 & -0.339 & -0.366 & 0.062 & 0.101 & 0.048 & -0.115 & -0.138 \\
\hline Panel mean & 0.452 & $-0.122^{b}$ & $-0.128^{a}$ & $-0.132^{\mathrm{a}}$ & $-0.230^{b}$ & $-0.241^{b}$ & -0.457 & -0.012 & 0.025 & 0.037 & 0.045 & 0.048 \\
\hline
\end{tabular}


Table 6. The mean returns (\%) of large weekend gaps and subsequent horizons in the overreaction test using the top and bottom $15 \%$ quantile as large gaps where ${ }^{\mathrm{a}}{ }^{\mathrm{b}}$ and ${ }^{\mathrm{c}}$ superscripts denote significance (i.e. difference from zero) at 1\%, 5\% and $10 \%$ levels respectively. The third row shows the end of the horizons including the European open (EU open) and US open for intraday horizons and the US close for daily horizons. All horizons start after the large weekend gap at the Australian open (AU open) on Monday. Panel A and B include major and emerging currencies respectively.

\begin{tabular}{|c|c|c|c|c|c|c|c|c|c|c|c|c|}
\hline & \multicolumn{6}{|c|}{ Upward gaps } & \multicolumn{6}{|c|}{ Downward gaps } \\
\hline & $\begin{array}{c}\text { Large gap } \\
\text { AU open }\end{array}$ & EU open & $\begin{array}{l}\text { One-day } \\
\text { US open }\end{array}$ & US close & $\begin{array}{l}\text { Three-day } \\
\text { US close }\end{array}$ & $\begin{array}{c}\text { One-week } \\
\text { US close }\end{array}$ & $\begin{array}{c}\text { Large gap } \\
\text { AU open }\end{array}$ & EU open & $\begin{array}{l}\text { One-day } \\
\text { US open }\end{array}$ & US close & $\begin{array}{l}\text { Three-day } \\
\text { US close }\end{array}$ & $\begin{array}{l}\text { One-week } \\
\text { US close }\end{array}$ \\
\hline \multicolumn{13}{|c|}{ Panel A: Major Currencies } \\
\hline EUR/USD & 0.216 & -0.012 & $-0.101^{\mathrm{c}}$ & $-0.165^{b}$ & $-0.337^{a}$ & $-0.257^{\mathrm{c}}$ & -0.292 & 0.036 & 0.007 & 0.093 & 0.249 & 0.374 \\
\hline JPY/USD & 0.366 & -0.034 & -0.007 & -0.030 & -0.079 & -0.024 & -0.282 & $0.075^{b}$ & $0.090^{\mathrm{b}}$ & $0.128^{b}$ & $0.271^{\mathrm{b}}$ & $0.291^{\mathrm{c}}$ \\
\hline GBP/USD & 0.237 & $-0.074^{b}$ & -0.072 & -0.062 & 0.024 & 0.058 & -0.238 & $0.060^{\mathrm{b}}$ & 0.011 & 0.105 & $0.207^{\mathrm{c}}$ & 0.165 \\
\hline AUD/USD & 0.369 & -0.005 & 0.022 & 0.036 & -0.021 & 0.067 & -0.273 & 0.043 & 0.045 & 0.107 & -0.127 & -0.047 \\
\hline CHF/USD & 0.337 & $-0.086^{c}$ & -0.090 & $-0.195^{a}$ & -0.113 & -0.035 & -0.264 & 0.014 & 0.041 & 0.072 & -0.042 & 0.080 \\
\hline NZD/USD & 0.327 & -0.058 & -0.042 & -0.066 & $-0.272^{c}$ & -0.097 & -0.392 & -0.019 & 0.031 & 0.087 & 0.355 & 0.440 \\
\hline Panel mean & 0.288 & $-0.041^{b}$ & $-0.038^{c}$ & -0.057 & $-0.117^{c}$ & -0.033 & -0.264 & $0.037^{\mathrm{b}}$ & $0.034^{\mathrm{b}}$ & $0.086^{\mathrm{a}}$ & $0.142^{\mathrm{c}}$ & $0.191^{\mathrm{b}}$ \\
\hline \multicolumn{13}{|c|}{ Panel B: Emerging Currencies } \\
\hline BRL/USD & 0.380 & -0.001 & -0.011 & $-0.047^{b}$ & $-0.301^{b}$ & -0.345 & -0.217 & $0.044^{\mathrm{c}}$ & $0.071^{\mathrm{c}}$ & 0.018 & -0.042 & -0.113 \\
\hline CZK/USD & 0.196 & -0.058 & -0.050 & -0.050 & -0.013 & 0.003 & -0.131 & 0.003 & 0.023 & 0.027 & 0.112 & 0.218 \\
\hline INR/USD & 0.477 & $-0.161^{\mathrm{a}}$ & $-0.204^{\mathrm{a}}$ & -0.099 & -0.145 & -0.021 & -0.141 & -0.017 & -0.050 & 0.071 & 0.063 & $0.159^{\mathrm{c}}$ \\
\hline IDR/USD & 0.454 & $-0.090^{b}$ & $-0.104^{b}$ & $-0.143^{\mathrm{a}}$ & $-0.217^{\mathrm{a}}$ & $-0.167^{b}$ & -0.435 & 0.005 & 0.029 & $0.071^{b}$ & 0.096 & $-0.170^{b}$ \\
\hline MXN/USD & 0.153 & -0.009 & 0.015 & 0.002 & -0.061 & 0.026 & -0.272 & $0.040^{\mathrm{c}}$ & 0.010 & -0.028 & 0.023 & -0.169 \\
\hline PLN/USD & 0.418 & 0.004 & $-0.217^{b}$ & $-0.278^{a}$ & -0.255 & -0.317 & -0.400 & -0.044 & 0.052 & -0.024 & 0.105 & 0.301 \\
\hline THB/USD & 0.138 & $-0.237^{c}$ & $-0.134^{c}$ & -0.053 & 0.017 & 0.069 & -0.120 & -0.207 & -0.009 & 0.032 & -0.012 & 0.055 \\
\hline TRY/USD & 0.224 & $-0.119^{a}$ & -0.055 & -0.100 & $-0.235^{c}$ & -0.251 & -0.259 & 0.027 & 0.023 & -0.141 & -0.209 & -0.317 \\
\hline Panel mean & 0.318 & $-0.094^{b}$ & $-0.099^{\mathrm{a}}$ & $-0.109^{a}$ & $-0.163^{a}$ & $-0.141^{b}$ & -0.265 & -0.012 & 0.016 & 0.015 & 0.026 & 0.046 \\
\hline
\end{tabular}


For ease of interpretation, we summarise Table $4-6$ in Table 7 and 8 below. Table 7 summarises the directional behaviours of mean returns of subsequent horizons after the large gaps, showing the number of negative returns, statistically significant negative returns, positive returns and statistically significant positive returns for major currencies as a whole and emerging currencies as a whole. Table 8 reports only the group average returns of major and emerging currencies (i.e. 'panel mean' in Table 4 $-6)$.

Table 7. Directional behaviours of mean returns of subsequent horizons. This table shows the number of negative returns, statistically significant negative returns, positive returns and statistically significant positive returns for major currencies as a whole and emerging currencies as a whole. The total number of returns is 35 for major currencies ( 7 pairs times 5 horizons) and 45 for emerging currencies ( 9 pairs times 5 horizons).

\begin{tabular}{|c|c|c|c|c|c|c|c|c|}
\hline & \multicolumn{4}{|c|}{ Upward gaps } & \multicolumn{4}{|c|}{ Downward gaps } \\
\hline & \multicolumn{2}{|c|}{ Negative } & \multicolumn{2}{|c|}{ Positive } & \multicolumn{2}{|c|}{ Positive } & \multicolumn{2}{|c|}{ Negative } \\
\hline & Total & Significant & Total & Significant & Total & Significant & Total & Significant \\
\hline \multicolumn{9}{|c|}{ Panel A: Major Currencies } \\
\hline $5 \%$ quantile & 24 & 9 & 11 & 0 & 30 & 8 & 5 & 0 \\
\hline $10 \%$ quantile & 27 & 8 & 8 & 1 & 27 & 4 & 8 & 0 \\
\hline $15 \%$ quantile & 27 & 16 & 8 & 0 & 31 & 8 & 4 & 0 \\
\hline \multicolumn{9}{|c|}{ Panel B: Emerging Currencies } \\
\hline $5 \%$ quantile & 40 & 20 & 5 & 0 & 34 & 9 & 11 & 0 \\
\hline $10 \%$ quantile & 39 & 19 & 6 & 0 & 30 & 7 & 15 & 1 \\
\hline $15 \%$ quantile & 38 & 16 & 7 & 0 & 29 & 5 & 16 & 1 \\
\hline
\end{tabular}

Table 8. Group average returns (\%) of large weekend gaps and subsequent horizons in the overreaction test using the top and bottom quantiles as large gaps where ${ }^{\mathrm{a}},{ }^{\mathrm{b}}$ and ${ }^{\mathrm{c}}$ superscripts denote significance (i.e. difference from zero) at $1 \%, 5 \%$ and $10 \%$ levels respectively. The second row shows the end of the horizons including the European open (EU open) and US open for intraday horizons and the US close for daily horizons. All horizons start after the large weekend gap at the Australian open (AU open) on Monday. Top and bottom quantiles refer to upward and downward gaps respectively.

\begin{tabular}{|c|c|c|c|c|c|c|}
\hline & $\begin{array}{l}\text { Large gap } \\
\text { AU open }\end{array}$ & EU open & $\begin{array}{l}\text { One-day } \\
\text { US open }\end{array}$ & US close & $\begin{array}{l}\text { Three-day } \\
\text { US close }\end{array}$ & $\begin{array}{l}\text { One-week } \\
\text { US close }\end{array}$ \\
\hline \multicolumn{7}{|c|}{ Panel A: Major Currencies } \\
\hline Top 5\% quantile & 0.444 & -0.040 & -0.018 & $-0.131^{c}$ & -0.184 & -0.326 \\
\hline Top $10 \%$ quantile & 0.369 & $-0.051^{\mathrm{c}}$ & -0.060 & -0.091 & $-0.163^{c}$ & -0.114 \\
\hline Top 15\% quantile & 0.288 & $-0.041^{b}$ & $-0.038^{c}$ & -0.057 & $-0.117^{c}$ & -0.033 \\
\hline Bottom $5 \%$ quantile & -0.407 & $0.047^{c}$ & 0.055 & $0.239^{\mathrm{a}}$ & 0.168 & $0.431^{\mathrm{a}}$ \\
\hline Bottom $10 \%$ quantile & -0.335 & $0.039^{b}$ & 0.014 & $0.077^{\mathrm{b}}$ & $0.149^{b}$ & $0.164^{b}$ \\
\hline \multirow{2}{*}{\multicolumn{7}{|c|}{ Panel B: Emerging Currencies }} \\
\hline & & & & & & \\
\hline Top 5\% quantile & 0.718 & $-0.198^{b}$ & $-0.158^{b}$ & $-0.436^{a}$ & $-0.294^{b}$ & $-0.774^{a}$ \\
\hline Top $10 \%$ quantile & 0.452 & $-0.122^{b}$ & $-0.128^{a}$ & $-0.132^{a}$ & $-0.230^{\mathrm{b}}$ & $-0.241^{b}$ \\
\hline Top $15 \%$ quantile & 0.318 & $-0.094^{b}$ & $-0.099^{\mathrm{a}}$ & $-0.109^{a}$ & -0.163 a & $-0.141^{b}$ \\
\hline Bottom 5\% quantile & -0.769 & 0.012 & $0.047^{\mathrm{c}}$ & $0.305^{\mathrm{a}}$ & 0.114 & $0.332^{\mathrm{b}}$ \\
\hline Bottom $10 \%$ quantile & -0.457 & -0.012 & 0.025 & 0.037 & 0.045 & 0.048 \\
\hline Bottom $15 \%$ quantile & -0.265 & -0.012 & 0.016 & 0.015 & 0.026 & 0.046 \\
\hline
\end{tabular}


As shown in Table 7, the majority of mean returns of subsequent horizons after a positive (negative) gap are negative (positive) and there is almost no significant momentum (i.e. positive returns after upward gaps and negative returns after downward gaps). Therefore, our results show strong evidence of large weekend gaps due to overreaction in these currency markets. The proportion of significant reversals (i.e. negative returns after upward gaps and positive returns after downward gaps) is higher for upward gaps than for downward gaps, and often lower for major currencies than for emerging currencies. The results are most pronounced for the $5 \%$ quantile, evidenced by the highest proportion of significant reversals and zero significant momentum. On the other hand, Table 8 shows that after large weekend gaps, the currency pairs often reverse gradually throughout the week and their reversals are often largest at the end of the week. In general, major currencies show smaller gaps and reversals than emerging currencies, the 5\% quantiles show the largest reversals and the top quantiles show larger reversals than the bottom quantiles.

\subsection{Trading strategy}

Because the previous analysis shows that overreaction and reversals are most significant for the 5\% quantiles in the one-week horizon, we examine our reversal trading strategy based on overreaction using the top and bottom 5\% quantiles of weekend returns as the entry signal and the one-week horizon as the trading horizon. We test the strategy out-of-sample starting in January 2007, which means in the first week of 2007, a trade will be initiated if the weekend gap exceeds the 'large gap' threshold estimated by the top and bottom 5\% quantile of gap returns during $2002-$ 2006 period. Including the financial crisis in the out-of-sample period helps us test the robustness of the trading strategy. The test moves forward week by week until May 2014, using both recursive and rolling estimation of large gaps. To adjust the trading returns for risks, we regress them against the currency risk factors used by Lustig et al. (2011). We report the regression results in Table 9 as well as other aspects of the strategy including the drawdown (Table 10) and the distribution of profitable signals over time (Figure 2). 
Table 9. Results of regression (11). The dependent variable is returns of the trading strategy using both recursive and rolling approach. The independent variables are currency risk factors including the average currency return (RX) and the carry trade return (HML). The intercept $\alpha$ is the abnormal return (\%). The standard errors are provided in brackets. ${ }^{\mathrm{a}}{ }^{\mathrm{b}}$ and $^{\mathrm{c}}$ superscripts denote statistical significance at 1\%,5\% and 10\% level respectively. Panel A and B include major and emerging currencies respectively. The 'Group' row is obtained by trading a portfolio including all currencies in the panel.

\begin{tabular}{|c|c|c|c|c|c|c|c|c|}
\hline & \multicolumn{4}{|c|}{ Recursive } & \multicolumn{4}{|c|}{ Rolling } \\
\hline & $\alpha$ & $\beta_{R X}$ & $\beta_{H M L}$ & Adjusted $\mathrm{R}^{2}$ & $\alpha$ & $\beta_{R X}$ & $\beta_{H M L}$ & Adjusted $\mathrm{R}^{2}$ \\
\hline \multicolumn{9}{|c|}{ Panel A: Major Currencies } \\
\hline EUR/USD & 0.04 & $0.0640^{a}$ & 0.0348 & 0.0315 & 0.04 & $0.0714^{\mathrm{a}}$ & 0.0291 & 0.0312 \\
\hline & $(0.03)$ & $(0.0246)$ & $(0.0281)$ & & $(0.03)$ & $(0.0258)$ & $\begin{array}{l}(0.0294) \\
-0.0497^{c}\end{array}$ & \\
\hline JPY/USD & $\begin{array}{c}0.00 \\
(0.02)\end{array}$ & $\begin{array}{l}0.0515^{b} \\
(0.0229)\end{array}$ & $\begin{array}{l}-0.0451^{c} \\
(0.0262)\end{array}$ & 0.0093 & $\begin{array}{c}0.00 \\
(0.02)\end{array}$ & $\begin{array}{l}0.0389^{c} \\
(0.0224)\end{array}$ & $\begin{array}{l}-0.0497^{c} \\
(0.0256)\end{array}$ & 0.0068 \\
\hline GBP/USD & $\begin{array}{l}0.07^{c} \\
(0.04)\end{array}$ & $\begin{array}{c}-0.1279^{a} \\
(0.0417)\end{array}$ & $\begin{array}{c}0.0525 \\
(0.0476)\end{array}$ & 0.0192 & $\begin{array}{l}0.08^{c} \\
(0.04)\end{array}$ & $\begin{array}{l}-0.1187^{a} \\
(0.0417)\end{array}$ & $\begin{array}{c}0.0524 \\
(0.0476)\end{array}$ & 0.0158 \\
\hline AUD/USD & $\begin{array}{c}0.01 \\
(0.07)\end{array}$ & $\begin{array}{l}-0.0418 \\
(0.0630)\end{array}$ & $\begin{array}{l}0.1717^{b} \\
(0.0719)\end{array}$ & 0.0102 & $\begin{array}{c}0.02 \\
(0.07)\end{array}$ & $\begin{array}{c}-0.0013 \\
(0.0618)\end{array}$ & $\begin{array}{l}0.1877^{a} \\
(0.0705)\end{array}$ & 0.0179 \\
\hline CHF/USD & $\begin{array}{l}0.05^{b} \\
(0.03)\end{array}$ & $\begin{array}{c}0.0129 \\
(0.0237)\end{array}$ & $\begin{array}{l}-0.0125 \\
(0.0270)\end{array}$ & -0.0043 & $\begin{array}{l}0.05^{c} \\
(0.03)\end{array}$ & $\begin{array}{c}0.0113 \\
(0.0240)\end{array}$ & $\begin{array}{l}-0.0077 \\
(0.0274)\end{array}$ & -0.0046 \\
\hline CAD/USD & $\begin{array}{c}0.00 \\
(0.03)\end{array}$ & $\begin{array}{l}-0.0375 \\
(0.0267)\end{array}$ & $\begin{array}{c}0.0397 \\
(0.0305)\end{array}$ & 0.0013 & $\begin{array}{c}0.01 \\
(0.03)\end{array}$ & $\begin{array}{c}-0.0069 \\
(0.0240)\end{array}$ & $\begin{array}{c}0.0320 \\
(0.0274)\end{array}$ & -0.0014 \\
\hline NZD/USD & $\begin{array}{l}0.19^{a} \\
(0.05)\end{array}$ & $\begin{array}{l}-0.1053^{b} \\
(0.0469)\end{array}$ & $\begin{array}{l}-0.0579 \\
(0.0536)\end{array}$ & 0.0225 & $\begin{array}{l}0.20^{\mathrm{a}} \\
(0.05)\end{array}$ & $\begin{array}{l}-0.1037^{b} \\
(0.0478)\end{array}$ & $\begin{array}{l}-0.0709 \\
(0.0546)\end{array}$ & 0.0243 \\
\hline Group & $\begin{array}{l}0.05^{b} \\
(0.02)\end{array}$ & $\begin{array}{c}-0.0263 \\
(0.0202)\end{array}$ & $\begin{array}{c}0.0262 \\
(0.0230)\end{array}$ & 0.0001 & $\begin{array}{l}0.06^{a} \\
(0.02)\end{array}$ & $\begin{array}{c}-0.0156 \\
(0.0202)\end{array}$ & $\begin{array}{c}0.0247 \\
(0.0231)\end{array}$ & -0.0020 \\
\hline \multicolumn{9}{|c|}{ Panel B: Emerging Currencies } \\
\hline $\mathrm{BRL} / \mathrm{USD}$ & $\begin{array}{c}0.04 \\
(0.06)\end{array}$ & $\begin{array}{l}-0.0558 \\
(0.0561)\end{array}$ & $\begin{array}{c}0.0089 \\
(0.0641)\end{array}$ & -0.0023 & $\begin{array}{c}0.06 \\
(0.06)\end{array}$ & $\begin{array}{l}-0.0513 \\
(0.0552)\end{array}$ & $\begin{array}{c}0.0136 \\
(0.0630)\end{array}$ & -0.0028 \\
\hline CZK/USD & $\begin{array}{c}0.00 \\
(0.04)\end{array}$ & $\begin{array}{c}0.0252 \\
(0.0405)\end{array}$ & $\begin{array}{c}0.0680 \\
(0.0462)\end{array}$ & 0.0062 & $\begin{array}{c}0.01 \\
(0.04)\end{array}$ & $\begin{array}{c}0.0063 \\
(0.0400)\end{array}$ & $\begin{array}{c}0.0289 \\
(0.0456)\end{array}$ & -0.0035 \\
\hline INR/USD & $\begin{array}{l}-0.05^{c} \\
(0.03)\end{array}$ & $\begin{array}{c}-0.0212 \\
(0.0259)\end{array}$ & $\begin{array}{l}0.0872^{a} \\
(0.0295)\end{array}$ & 0.0181 & $\begin{array}{l}-0.04 \\
(0.03)\end{array}$ & $\begin{array}{l}-0.0284 \\
(0.0254)\end{array}$ & $\begin{array}{l}0.0952^{a} \\
(0.0290)\end{array}$ & 0.0229 \\
\hline IDR/USD & $\begin{array}{l}0.06^{c} \\
(0.03)\end{array}$ & $\begin{array}{c}0.0020 \\
(0.0308)\end{array}$ & $\begin{array}{c}0.0295 \\
(0.0351)\end{array}$ & -0.0027 & $\begin{array}{l}0.06^{c} \\
(0.03)\end{array}$ & $\begin{array}{c}-0.0206 \\
(0.0278)\end{array}$ & $\begin{array}{l}0.0652^{b} \\
(0.0317)\end{array}$ & 0.0059 \\
\hline MXN/USD & $\begin{array}{l}0.11^{a} \\
(0.04)\end{array}$ & $\begin{array}{c}-0.1544^{a} \\
(0.0375)\end{array}$ & $\begin{array}{l}0.1098^{b} \\
(0.0429)\end{array}$ & 0.0384 & $\begin{array}{l}0.09^{b} \\
(0.04)\end{array}$ & $\begin{array}{c}-0.1603^{a} \\
(0.0360)\end{array}$ & $\begin{array}{l}0.0999^{b} \\
(0.0411)\end{array}$ & 0.0445 \\
\hline PLN/USD & $\begin{array}{c}0.05 \\
(0.07)\end{array}$ & $\begin{array}{l}-0.0526 \\
(0.0629)\end{array}$ & $\begin{array}{l}0.2225^{a} \\
(0.0718)\end{array}$ & 0.0206 & $\begin{array}{c}0.02 \\
(0.06)\end{array}$ & $\begin{array}{c}-0.0521 \\
(0.0569)\end{array}$ & $\begin{array}{l}0.2285^{a} \\
(0.0649)\end{array}$ & 0.0279 \\
\hline ZAR/USD & $\begin{array}{c}0.09 \\
(0.06)\end{array}$ & $\begin{array}{l}-0.0396 \\
(0.0516)\end{array}$ & $\begin{array}{l}0.1735^{a} \\
(0.0589)\end{array}$ & 0.0182 & $\begin{array}{c}0.09 \\
(0.05)\end{array}$ & $\begin{array}{c}-0.0274 \\
(0.0504)\end{array}$ & $\begin{array}{l}0.1825^{a} \\
(0.0575)\end{array}$ & 0.0234 \\
\hline THB/USD & $\begin{array}{l}-0.01 \\
(0.03)\end{array}$ & $\begin{array}{c}0.0389 \\
(0.0285)\end{array}$ & $\begin{array}{l}-0.0139 \\
(0.0326)\end{array}$ & -0.0002 & $\begin{array}{c}-0.01 \\
(0.03)\end{array}$ & $\begin{array}{c}0.0285 \\
(0.0284)\end{array}$ & $\begin{array}{c}-0.0069 \\
(0.0324)\end{array}$ & -0.0023 \\
\hline TRY/USD & $\begin{array}{l}-0.04 \\
(0.05)\end{array}$ & $\begin{array}{l}0.0982^{b} \\
(0.0424)\end{array}$ & $\begin{array}{l}0.1933^{a} \\
(0.0484)\end{array}$ & 0.0867 & $\begin{array}{c}-0.02 \\
(0.05)\end{array}$ & $\begin{array}{l}0.1080^{b} \\
(0.0452)\end{array}$ & $\begin{array}{l}0.2108^{a} \\
(0.0516)\end{array}$ & 0.0907 \\
\hline Group & $\begin{array}{c}0.03 \\
(0.02)\end{array}$ & $\begin{array}{l}-0.0177 \\
(0.0189)\end{array}$ & $\begin{array}{l}0.0977^{a} \\
(0.0215)\end{array}$ & 0.0501 & $\begin{array}{c}0.03 \\
(0.02)\end{array}$ & $\begin{array}{l}-0.0219 \\
(0.0184)\end{array}$ & $\begin{array}{l}0.1020^{a} \\
(0.0210)\end{array}$ & 0.0565 \\
\hline
\end{tabular}


Table 10. Maximum drawdown (\%) of the reversal strategy. Panel A and B include major and emerging currencies respectively.

\begin{tabular}{|ccc|}
\hline & Recursive & Rolling \\
\hline Panel A: Major & Currencies & \\
EUR/USD & 5.957 & 5.957 \\
JPY/USD & 14.585 & 13.246 \\
GBP/USD & 9.825 & 9.825 \\
AUD/USD & 24.067 & 24.067 \\
CHF/USD & 2.692 & 2.315 \\
CAD/USD & 8.883 & 6.522 \\
NZD/USD & 3.996 & 3.996 \\
Panel mean & 10.001 & 9.418 \\
Panel B: Emerging Currencies & \\
BRL/USD & 19.170 & 19.170 \\
CZK/USD & 18.390 & 15.992 \\
INR/USD & 23.416 & 20.806 \\
IDR/USD & 7.171 & 7.171 \\
MXN/USD & 5.972 & 5.235 \\
PLN/USD & 21.610 & 20.568 \\
ZAR/USD & 11.584 & 11.584 \\
THB/USD & 11.348 & 11.348 \\
TRY/USD & 16.774 & 12.943 \\
Panel mean & 15.048 & 13.869 \\
\hline
\end{tabular}


Figure 2. Distribution of profitable trades over time. This figure shows the distribution of profitable trades generated by the reversal strategy over time using recursive and rolling estimation of 'large gap' signals. The vertical axis shows the return of each trade (\%).
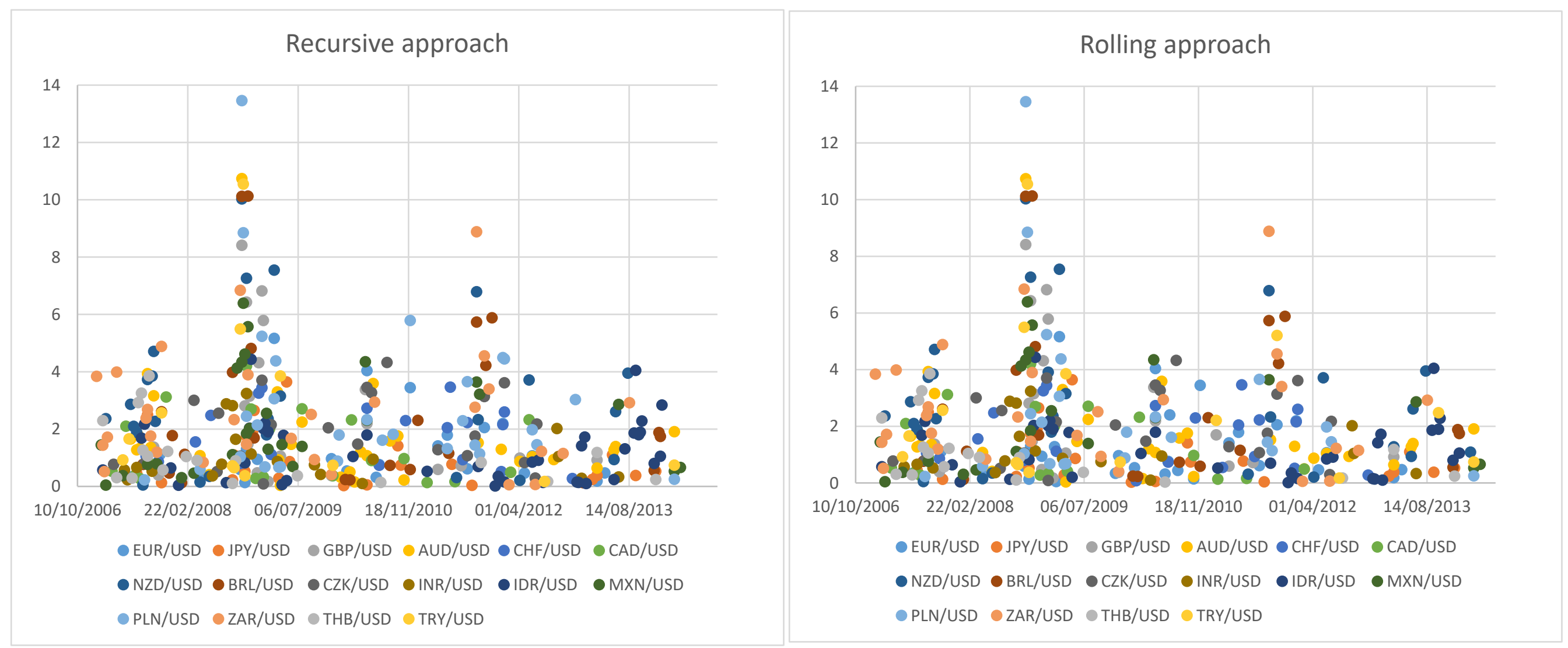
Table 9 above shows that the regression results are similar for both the recursive and rolling approach of the trading strategy. Although statistically significant in some cases, the currency risk factors have limited explanatory power for variations in trading returns as shown by the low $\mathrm{R}^{2}$ values, which means that the trading strategy is not sensitive to systematic risks. The abnormal return $\alpha$ is statistically significant for both major and emerging currencies as well as for both individual currencies and portfolio. Because the trading horizon is one week, the abnormal return in Table 9 is a weekly average. NZD/USD generates the most significant abnormal return, which is $0.2 \%$ per week and thus $10.4 \%$ per annum. Regarding the drawdown of the trading strategy (Table 10), it ranges from $2.3 \%$ to $24.1 \%$ and is often lower for major currencies than for emerging currencies while higher for the recursive approach than for the rolling approach. As shown in Figure 2, profitable trades are distributed similarly for both the recursive and rolling approach. These trades occur regularly throughout the trading period with two clusters of highly profitable trades during 2008 -2009 and $2011-2012$, and the strategy performs well in the financial crisis.

\section{Conclusion}

We find a calendar effect, namely the weekend overreaction, in spot FX rates of 7 major and 9 emerging currency pairs, evidenced by reversals in multiple horizons during the week after large weekend gaps. A contrarian strategy is designed to exploit this effect. In the out-of-sample trading test, the strategy is able to generate abnormal risk-adjusted returns after including transaction costs and interest rates, which suggests the possibility of weak-form inefficiency in these currency markets. 


\section{References}

Alonso, A. and Rubio, G. (1990) 'Overreaction in the Spanish Equity Market', Journal of Banking \& Finance, 14(2-3), 469-481.

Amini, S., Gebka, B., Hudson, R. and Keasey, K. (2013) 'A review of the international literature on the short term predictability of stock prices conditional on large prior price changes: Microstructure, behavioral and risk related explanations', International Review of Financial Analysis, 26, 1-17.

Antoniou, A., Galariotis, E. C. and Spyrou, S. I. (2005) 'Contrarian profits and the overreaction hypothesis: the case of the Athens Stock Exchange', European Financial Management, 11(1), 71-98.

Atkins, A. B. and Dyl, E. A. (1990) 'Price Reversals, Bid-Ask Spreads, and MarketEfficiency', Journal of Financial and Quantitative Analysis, 25(4), 535-547.

Barberis, N., Shleifer, A. and Vishny, R. (1998) 'A model of investor sentiment', Journal of Financial Economics, 49, 307-344.

Bauman, W. S., Conover, C. M. and Miller, R. E. (1999) 'Investor overreaction in international stock markets - Value stocks outperform outside the U.S.', Journal of Portfolio Management, 25(4), 102-111.

Bessembinder, H. (1994) 'Bid-Ask Spreads in the Interbank Foreign-Exchange Markets', Journal of Financial Economics, 35(3), 317-348.

Cox, D. R. and Peterson, D. R. (1994) 'Stock Returns Following Large One-Day Declines - Evidence on Short-Term Reversals and Longer-Term Performance', Journal of Finance, 49(1), 255-267.

Daniel, K., Hirshleifer, D. and Subrahmanyam, A. (2001) 'Overconfidence, arbitrage and equilibrium asset pricing', Journal of Finance, 56, 921-965.

Debondt, W. F. M. and Thaler, R. (1985) 'Does the Stock-Market Overreact', Journal of Finance, 40(3), 793-805.

Debondt, W. F. M. and Thaler, R. H. (1987) 'Further Evidence on Investor Overreaction and Stock-Market Seasonality', Journal of Finance, 42(3), 557581.

Ederington, L. H. and Lee, J. H. (1995) 'The Short-Run Dynamics of the Price Adjustment to New Information', Journal of Financial and Quantitative Analysis, 30(1), 117-134.

French, K. R. and Roll, R. (1986) 'Stock Return Variances - the Arrival of Information and the Reaction of Traders', Journal of Financial Economics, 17(1), 5-26. 
Fung, A. K. W., Mok, D. M. Y. and Lam, K. (2000) 'Intraday price reversals for index futures in the US and Hong Kong', Journal of Banking \& Finance, 24(7), $1179-1201$.

Goodhart, C. (1988) 'The Foreign-Exchange Market - a Random-Walk with a Dragging Anchor', Economica, 55(220), 437-460.

Ito, T., Lyons, R. K. and Melvin, M. T. (1998) 'Is there private information in the FX market? The Tokyo experiment', Journal of Finance, 53(3), 1111-1130.

Jegadeesh, N. and Titman, S. (1995) 'Overreaction, delayed reaction, and contrarian profits', Review of Financial Studies, 8(4), 973-993.

Jensen, M. C. (1978) 'Some anomalous evidence regarding market efficiency', Journal of Financial Economics, 6, 95-101.

Kho, B. C. (1996) 'Time-varying risk premia, volatility, and technical trading rule profits: Evidence from foreign currency futures markets', Journal of Financial Economics, 41(2), 249-290.

Kuang, P., Schroder, M. and Wang, Q. (2014) 'Illusory profitability of technical analysis in emerging foreign exchange markets', International Journal of Forecasting, 30(2), 192-205.

Larson, S. J. and Madura, J. (2001) 'Overreaction and underreaction in the foreign exchange market', Global Finance Journal, 12, 153-177.

Lustig, H., Roussanov, N. and Verdelhan, A. (2011) 'Common Risk Factors in Currency Markets', Review of Financial Studies, 24(11), 3731-3777.

McFarland, J. W., Richardson Pettit, R. and Sung, S. K. (1982) 'The distribution of foreign exchange price changes: trading day effects and risk measurement', Journal of Finance, 37(3), 693-715.

Menkhoff, L., Sarno, L., Schmeling, M. and Schrimpf, A. (2012) 'Currency momentum strategies', Journal of Financial Economics, 106, 660-684.

Parikakis, G. S. and Syriopoulos, T. (2008) 'Contrarian strategy and overreaction in foreign exchange markets', Research in International Business and Finance, $22,319-324$

Qi, M. and Wu, Y. R. (2006) 'Technical trading-rule profitability, data snooping, and reality check: Evidence from the foreign exchange market', Journal of Money Credit and Banking, 38(8), 2135-2158.

Rentzler, J., Tandon, K. and Yu, S. (2006) 'Intraday price-reversal patterns in the currency futures market The impact of the introduction of GLOBEX and the euro, Journal of Futures Markets Volume 26, Issue 11', Journal of Futures Markets, 26(11), 1089-1130. 
Rogalski, R. J. (1984) 'New Findings Regarding Day-of-the-Week Returns over Trading and Non-Trading Periods', Journal of Finance, 39(5), 1603-1614.

Urquhart, A. and McGroarty, F. (2014) 'Calendar effects, market conditions and the Adaptive Market Hypothesis: Evidence from long-run U.S. data', International Review of Financial Analysis, 35, 154-166.

White, H. (2000) 'A reality check for data snooping', Econometrica, 68(5), 10971126.

Zarowin, P. (1990) 'Size, Seasonality, and Stock-Market Overreaction', Journal of Financial and Quantitative Analysis, 25(1), 113-125. 